OPEN ACCESS

Edited by:

Meral Beksac,

Ankara University School of Medicine,

Turkey

Reviewed by:

Aurore Saudemont,

University College London, UK

Katia Gagne,

Etablissement Français du Sang,

France

${ }^{*}$ Correspondence:

Rohtesh S. Mehta

rsmehta@umn.edu;

Katayoun Rezvani

krezvani@mdanderson.org

Specialty section:

This article was submitted to

Hematology,

a section of the journal

Frontiers in Medicine

Received: 02 November 2015 Accepted: 10 December 2015

Published: 05 January 2016

Citation:

Mehta RS, Shpall EJ and Rezvani K (2016) Cord Blood as a Source of Natural Killer Cells. Front. Med. 2:93.

doi: 10.3389/fmed.2015.00093

\section{Cord Blood as a Source of Natural Killer Cells}

\author{
Rohtesh S. Mehta ${ }^{1 *}$, Elizabeth J. Shpall ${ }^{2}$ and Katayoun Rezvani ${ }^{2 *}$ \\ 'Division of Hematology, Oncology and Transplantation, University of Minnesota Medical Center, Minneapolis, MN, USA, \\ ${ }^{2}$ Department of Stem Cell Transplantation, Division of Cancer Medicine, The University of Texas MD Anderson Cancer \\ Center, Houston, TX, USA
}

Cord blood (CB) offers several unique advantages as a graft source for hematopoietic stem cell transplantation (HSCT). The risk of relapse and graft vs. host disease after cord blood transplantation (CBT) is lower than what is typically observed after other graft sources with a similar degree of human leukocyte antigen mismatch. Natural killer (NK) cells have a well-defined role in both innate and adaptive immunity and as the first lymphocytes to reconstitute after HSCT and CBT, and they play a significant role in protection against early relapse. In this article, we highlight the uses of CB NK cells in transplantation and adoptive immunotherapy. First, we will describe differences in the phenotype and functional characteristics of NK cells in CB as compared with peripheral blood. Then, we will review some of the obstacles we face in using resting CB NK cells for adoptive immunotherapy, and discuss methods to overcome them. We will review the current literature on killer-cell immunoglobulin-like receptors ligand mismatch and outcomes after CBT. Finally, we will touch on current strategies for the use of CB NK cells in cellular immunotherapy.

Keywords: cord blood, natural killer cells, adoptive immunotherapy, KIR mismatch, transplantation, CBT

\section{INTRODUCTION}

Cord blood $(\mathrm{CB})$ is a rich source of hematopoietic stem and progenitor cells and is being increasingly used as a graft source for hematopoietic stem cell transplantation (HSCT) (1). Despite the naive nature of CB T-lymphocytes $(2,3)$, the risk of relapse is lower after cord blood transplantation (CBT) compared with other donor sources (4-7). As natural killer (NK) cells are the first lymphocytes to reconstitute after HSCT and CBT (8-14) and their role in both innate and adaptive immunity is well characterized (15-17), it is likely that they play a crucial role in protection against early disease relapse. This article focuses on the uses of CB as a source of NK cells in CBT as well as in adoptive immunotherapy.

\section{NATURAL KILLER CELL PHENOTYPE}

Natural killer cells are immunophenotypically characterized as $\mathrm{CD} 3^{-} \mathrm{CD} 56^{+}$lymphocytes and are broadly classified into the less differentiated CD56 $6^{\text {bright }}$ or the mature CD56 ${ }^{\mathrm{dim}}$ populations $(16,18)$. CD56 $6^{\text {bright }}$ cells have low or absent expression of CD16 and killer-cell immunoglobulinlike receptors (KIR), whereas the $\mathrm{CD} 56^{\text {dim }}$ subset expresses both $\mathrm{CD} 16$ and $\mathrm{KIR}(18,19)$. Resting peripheral blood (PB) CD56 bright cells are poorly cytotoxic but are potent secretors of immunomodulatory cytokines and have tremendous proliferative capacity in response to IL-2. 
Conversely, PB CD56 ${ }^{\mathrm{dim}}$ cells are highly cytotoxic but have a poor capacity to proliferate in response to cytokines (16, $18-26)$.

\section{HOW DO CORD BLOOD NK CELLS DIFFER FROM PERIPHERAL BLOOD NK CELLS?}

Cord blood offers unique advantages, many of which are directly applicable to NK cell-directed alloreactivity. The ease of collection of $\mathrm{CB}$ and cryopreservation makes them readily available as an off-the-shelf source for NK cell immunotherapy $(27,28)$. Besides, the presence of almost a log fewer T-cells in CB compared to other graft sources (29-33), most of which are naive (34-36), minimizes the risk of graft vs. host disease (GVHD) (7, 29, 33, 37-40). More importantly, NK cell reconstitute more rapidly after CBT than PB HSCT $(41,42)$. One study showed that the absolute numbers of CD56 CD16 NK cells were significantly higher for up to 2 years after double unit CBT compared with filgrastim-mobilized unrelated donor PB HSCT (11). Moreover, CB contains unique cell populations, which represent NK-cell progenitors and are either absent or present in minute numbers in PB (43-49). These cells have a potential to differentiate into NK cells after ex vivo stimulation with cytokines, including IL-2 (48), IL-15, and/or FLT-3 ligand $(43,47,48)$. Data also suggest that CB CD56 ${ }^{\text {bright }} \mathrm{NK}$ cells (but not CB T-cells) produce significantly more IFN- $\gamma$ after stimulation with IL-12 and IL-18 compared with PB NK cells (36). This may in turn compensate for the hypofunctionality of naive CB T-cells - thus also contributing to a lower risk of GVHD while maintaining the crucial graft vs. leukemia effect. After stimulation with IL-12 and IL-18, the expression of CD69 (an activation marker) is increased appreciably on CB NK, but not PB NK cells (36). Moreover, the expression of CXCR4, a bone marrow (BM) homing receptor, is significantly higher in $\mathrm{CB} C D 56^{\text {bright }}$ and $\mathrm{CD} 56^{\mathrm{dim}} \mathrm{NK}$ cells compared with their $\mathrm{PB}$ counterparts (50), suggesting that CB NK cells may have better BM homing potential.

\section{LIMITATIONS OF CORD BLOOD AS A SOURCE OF NK CELLS}

There are also noteworthy limitations to the use of unmanipulated CB as a source of NK cells for immunotherapy. The foremost impediment relates to the finite number of $\mathrm{NK}$ cells available in a single $\mathrm{CB}$ unit. Although the frequencies of NK cells in $\mathrm{PB}$ and $\mathrm{CB}$ are similar (50-53), the small volume of blood in a CB unit makes it challenging to obtain adequate numbers needed for clinical use. A second crucial obstacle is the functional immaturity of resting CB NK cells. In contrast to PB, CB NK cells express very few inhibitory KIRs, have a higher expression of the inhibitory receptor NKG2A and almost completely lack CD57 expression, an activation marker associated with terminal differentiation of NK cells $(49,50,54,55)$. Moreover, the expression of other activation receptors, such as NKp46, NKG2C, and DNAM-1, are lower in CB NK cells (50). As a result, resting CB CD56 ${ }^{\text {dim }} \mathrm{NK}$ cells have poor in vitro cytotoxicity compared with PB NK cells.
To overcome these limitations, a number of groups have developed ex vivo expansion techniques that can increase NK cell numbers by about 1800- to 2400 -fold from either fresh or cryopreserved $\mathrm{CB}$ units (56). NK cells can also be successfully differentiated from $\mathrm{CB}$ CD $34^{+}$cells (57-60) using a cocktail of cytokines and membrane-bound IL-15 (60). Most expansion techniques use IL-2 either alone $(61,62)$ or in combination with IL-15 (63), or IL-7 (64), or stem cell factor and FLT3-ligand, (64) or a supporting layer of mesenchymal stromal cells (65), or artificial antigen-presenting cell, such as K562 cells expressing membrane-bound IL-21 (56). Expansion techniques not only augment $\mathrm{CB}$ NK cell numbers but also result in the acquisition of functional competence and similar activity to ex vivo activated PB NK cells (56).

\section{NK CELL ALLOREACTIVITY}

The alloreactivity of NK cells is guided by a fine balance between their activating and inhibitory receptors, and interactions with their cognate ligands. The inhibitory KIRs recognize classical MHC-I molecules (HLA- A, -B, and -C) C-type lectin family of receptors (CD94 and NKG2s - NKG2A, -B, -C, -D, -E, and -F) recognize non-classical MHC-I molecules (HLA-E and stressinduced MHC-I related chains - MICA and MICB), while the ligands for natural cytotoxicity receptors (NKp46, NKp30, NKp44, NKp80, and others) and activating KIRs are largely unknown [reviewed in Ref. (66-69)]. The recognition of "self" MHC-I molecules on normal cells by inhibitory NK receptors protects them from NK cell-mediated lysis (70, 71). However, malignant or infected cells often shed or down-regulate their MHC-I molecules as an immune escape mechanism $(72,73)$, which revokes NK cell inhibition and triggers the activating receptors to cause cell lysis $(74,75)$. This principle could be exploited to our advantage in HSCT because the human leukocyte antigen (HLA) system (chromosome 6) and KIR genes (chromosome 19q13.4) are located on different chromosomes and segregate independently $(76,77)$. This creates a possible scenario of donor-recipient HLAmatch appropriate for HSCT, yet retaining mismatch in KIRs and their ligands, yielding alloreactive NK cells against the recipient tumor cells.

\section{DIFFERENT MODELS USED TO DEFINE NK CELL ALLOREACTIVITY}

Before reviewing the clinical applicability of this concept, it is important to understand various methods used to assess NK cell alloreactivity. These include (a) testing donor NK KIR expression (genotype or phenotype) and the corresponding HLA [KIR-ligands (KIR-Ls)] in recipient, known as the receptor-ligand model, (b) determining HLA class I typing (KIR-Ls) in both donor and recipient, known as the ligand-ligand model, or (c) performing functional analysis of NK cell alloreactivity, where donor NK cells are tested for their ability to lyse a cell line or the recipient's leukemia cells, known as the cytotoxicity model (78-81). Likewise, the KIR repertoire in an individual can be determined based on either (a) KIR genotype (DNA-based methods to assess KIR 
genes, or real-time quantitative PCR to assess mRNA expression) or (b) KIR phenotype (using flow cytometry for surface protein expression), although most currently available monoclonal antibodies used for flow cytometry cannot differentiate activating from inhibitory KIRs. To make matters even more complicated, about one-quarter of individuals have discrepancies in the genotype and phenotype of four inhibitory KIRs (KIR2DL1, KIR2DL2, KIR2DL3, and KIR3DL1) (82). For instance, the gene for KIR2DL1 is present in $93-97 \%$ of individuals, yet the corresponding receptor is absent in $7 \%$, one or both allelic forms of KIR2DL2/KIR2DL3 exist in all individuals, and the gene for KIR3DL1 is present in about $90-92 \%$ of individuals, but about $15 \%$ of them do not express the corresponding receptor $(80,82)$.

Various studies evaluated transplant outcomes, using different models to predict NK cell alloreactivity. The earliest clinical evidence for the importance of NK alloreactivity in reducing the risk of relapse was provided by Ruggeri et al. $(78,83)$ in T-deplete haploidentical HSCT, using the KIR-L mismatch model to predict alloreactivity. Subsequent studies in the settings of haploidentical, matched or mismatched unrelated or unrelated donor HSCT produced surprisingly variable results, ranging from no advantage (84-88) to mixed response based on the type of KIR-L incompatibility model used for the analysis (81), to improvements in one or all aspects of relapse risk, disease free survival (DFS), or overall survival (OS) (79, 80, 89-93). However, caution is warranted in interpreting the results due to remarkable heterogeneity of these studies.

\section{ALLOREACTIVE NK CELLS IN CORD BLOOD TRANSPLANTATION}

Given the unique advantages offered by $\mathrm{CB}$, four relatively large studies assessed the role of KIR-L mismatch in the CBT setting (Table 1) (94-97). All but one (97) failed to demonstrate a beneficial effect of KIR-L mismatch on disease outcomes after CBT. One study (94) rather reported that KIR-L mismatch was associated with higher risk of acute GVHD, and worse treatment-related mortality (TRM) and OS after reduced intensity conditioning CBT (RIC-CBT). All of these studies used the KIR-L mismatch model proposed by Ruggeri et al. (78).

The first and the only CBT study to demonstrate any favorable effect of KIR-L mismatch was reported by Willemze et al. (97). The authors also included HLA A3/A11 (ligand for KIR3DL2) mismatches in their study, the role of which is quite controversial (98), because the interaction between KIR3DL2 and HLA-A3/ A11 occurs in the presence of specific viral peptides (99) and the evidence of their in vivo interaction is scare (100). The study included 149 KIR-L matched and 69 KIR-L mismatched donor-recipient pairs, with median recipient ages of 12.8 and 15 years, respectively. Only patients with AML or ALL were included, all of whom received single unit CBT. The majority received myeloablative conditioning (MAC) and ATG were used in 79 and $84 \%$ of patients, respectively. There were no differences in the incidence of acute or chronic GVHD or non-relapse mortality (NRM) between the KIR-L matched and mismatched groups. However, the probabilities of 2 -year relapse (37 vs. $20 \%$, $p=0.03$ ), 2-year DFS ( 40 vs. $55 \%, p=0.005)$, and 2 -year OS (31 vs. $57 \%, p=0.02$ ) were all significantly improved in the KIR-L mismatched group. In subgroup analysis, these differences were significant for patients with AML only. Furthermore, deaths due to opportunistic infections were more frequent in the KIR-L matched group (38 vs. $7 \%, p=0.03$ ). The median follow-up period (13 and 15 months) was relatively short, but the study findings remained unchanged in a later update with a median follow-up of 34 months (101).

In contrast, the Minnesota group (94) reported a detrimental impact of KIR-L mismatch in recipients of RIC CBT. The study included 183 KIR-L matched and 74 KIR-L mismatched donorrecipient pairs with a variety of hematological malignancies, including acute or chronic leukemias and lymphomas. Patients received either single or double unit CBT, the definition of KIR-L mismatch in the recipients of double CBT was arbitrarily defined based on the KIR-L of the dominant engrafting unit. Due to significant differences in the MAC and RIC groups, the results of these groups were reported separately. The MAC arm constituted primarily pediatric patients with median ages of 15 and 15.9 years in KIR-L matched and mismatched groups, respectively. The majority received single CBT (66 and 56\%) and ATG were used sparingly (41 and 38\%), respectively. As expected, patients who received RIC regimens were older with median ages of 48 and 52 years, respectively, and all underwent double unit CBT. Again, ATG was used in only a minority of patients (24 and 32\%, respectively). The follow-up duration (medians 1.8-2.2 years in all groups) was longer than in the Willemze study (97). This study did not find an impact of KIR-L mismatch on any of the clinical outcomes after MAC, including acute or chronic GVHD, TRM, relapse risk, or OS. Conversely, in the RIC group, KIR-L mismatch was associated with significantly higher rates of grades II-IV (79 vs. $57 \%, p=0.01$ ) and grades III-IV (42 vs. $13 \%, p \leq 0.01$ ) acute GVHD, worse TRM (27 vs. $12 \%, p=0.03$ ), and OS (32 vs. $52 \%, p=0.03$ ). In multivariate analysis, KIR-L mismatch was the only significant predictor of higher rates of grades III-IV acute GVHD (RR 1.8, 95\% CI $1.1-2.9 ; p=0.02$ ) and risk of death (RR 1.8; 95\% CI 1.0-3.1, $p=0.05)$. Restricting their analysis to only AML patients, the authors again found higher incidence of grades III-IV acute GVHD in patients with KIR-L mismatch. Analysis performed with or without the inclusion of HLA-A3/A11 mismatches did not affect clinical outcomes.

Similar findings were reported in the double CBT setting by the Boston group (95) without the inclusion of HLA-A3/A11 mismatches. They included patients with diverse hematological malignancies, three-quarters of whom received RIC regimens with fludarabine, melphalan, and ATG. The study found no impact of KIR-L mismatch on the incidence of acute or chronic GVHD, relapse, DFS, or OS. However, the KIR-L mismatched group experienced more graft rejections (5/35) compared with KIR-L matched group $(1 / 45, p=0.08)$. Interestingly, $4 / 5$ patients with graft rejection in the KIR-L mismatched group had cord vs. cord KIR-L mismatches and 3/5 had host vs. cord KIR-L mismatches. Later, a Japanese study (96) also found no impact of KIR-L (including HLA-A3/A11) mismatch in single unit CBT recipients with either AML or ALL. Of note, more than $80 \%$ of 


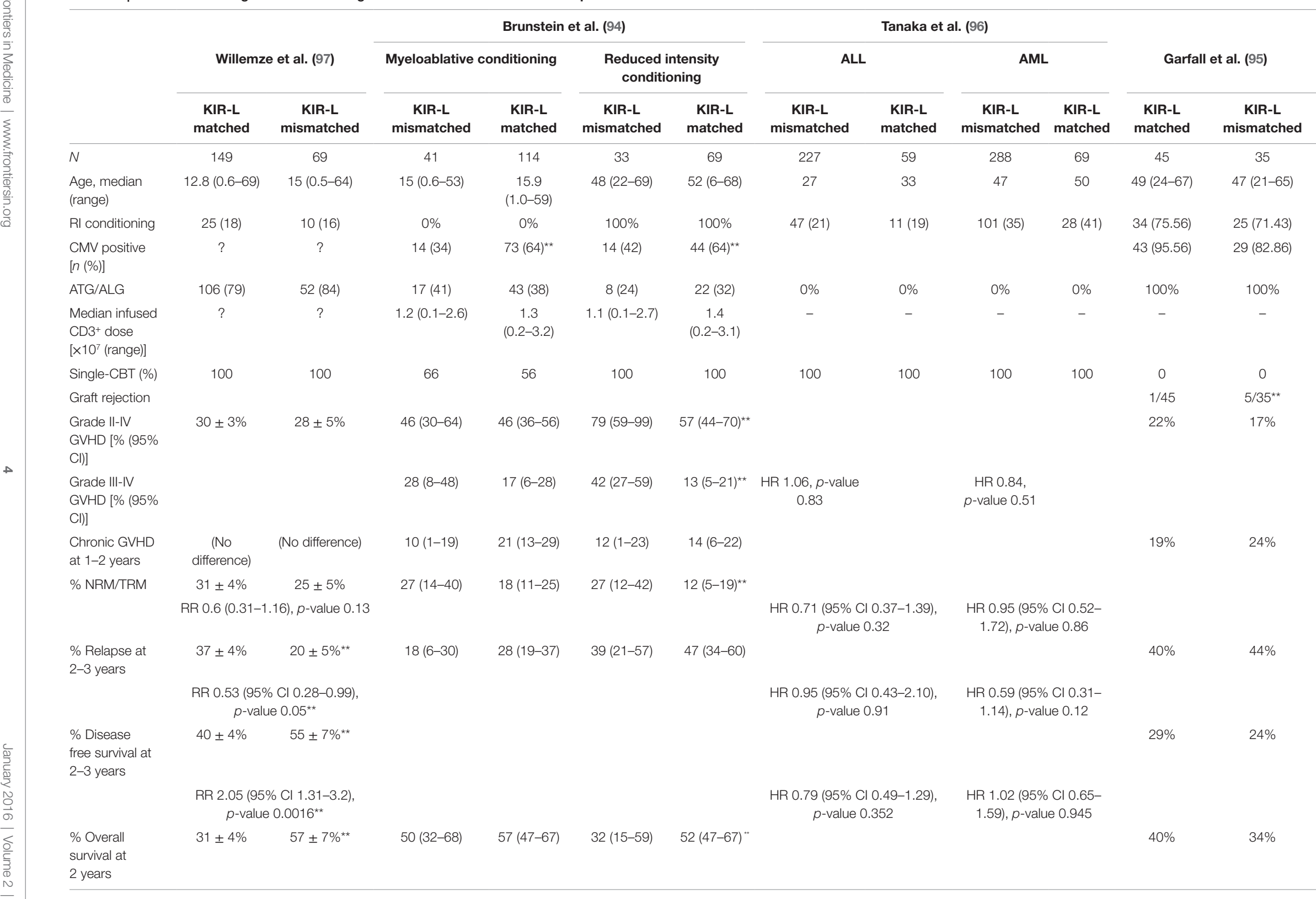


patients received TBI-based MAC regimens, but ATG was not used.

As noted, these studies are fairly heterogeneous in terms of their study population, underlying disease, use of single vs. double $\mathrm{CB}$ grafts, conditioning regimens, use of in vivo T-cell depletion, GVHD prophylaxis, inclusion of HLA-A3/A11 mismatch in the analysis, to name a few. The use of lymphodepleting chemotherapy regimens, such as high-dose cyclophosphamide and fludarabine with the addition of TBI supports in vivo expansion of adoptively transferred cytotoxic T-cells and NK cells (102-105). Also, T-cell depletion in the haploidentical HSCT setting is associated with more rapid NK cell immune reconstitution and strong NK-cell alloreactivity $(78,80,83)$. The use of double (instead of single) unit CBT introduces another level of complexity due to lack of our understanding of three way KIR-L interactions among the recipient and the two $\mathrm{CB}$ grafts. In such cases, NK cells from the "dominant" $\mathrm{CB}$ unit are presumed to be contributing to the beneficial NK alloreactivity (94), but the role of NK cells in the non-dominant $\mathrm{CB}$ unit and their influence in mediating donor vs. recipient and graft vs. graft alloreactivity is not clear.

\section{FUTURE CONSIDERATIONS}

\section{Role of CMV in Influencing NK Cell Alloreactivity Post Transplantation}

It is now well established that CMV infection or reactivation can reduce the risk of relapse after HSCT by enhancing NK cell maturation with increased CD56 $6^{\text {dim }}$ population, shaping NK cells toward an activated phenotype with upregulation of NKG2C (activation) and KIR receptors and downregulation of NKG2A (inhibitory) along with increased expression of CD57, and creating "memory NK cells" (106-112). It is plausible that some of the discrepancies noted in the four CBT studies described above could be due to differential CMV reactivation among the different groups. As an example, significantly more patients in the KIR-L matched group were CMV seropositive compared with the KIR-L mismatched group in the Minnesota study (94). By contrast, in the Willemze study (97), equal numbers of patients were CMV seropositive in both KIR-L matched and mismatched groups, whereas the Japanese study (96) did not report on the CMV serostatus of their cohort.

\section{Role of Activating NK Cell Receptors and NK Haplotypes}

Likewise, no study evaluated the role of activating KIRs on CBT outcomes, which are known to influence outcomes after other types of transplant $(88,113-117)$. The KIR genes are encoded as haplotypes, and individuals can be categorized as either haplotype A or B. Haplotype A individuals have more inhibitory KIRs, whereas haplotype B individuals carry more activating KIRs. The favorable effect of receiving grafts from haplotype B donors was demonstrated by Cooley et al. (117) in AML patients who underwent unrelated donor PB or BM HSCT. Patients whose donors had KIR-B/x haplotype (i.e., either homozygous or heterozygous B-haplotype) had improved relapse-free survival compared to those who received grafts from homozygous haplotype A donors. 
TABLE 2 | Ongoing clinical trials assessing the role of cord blood natural killer cells in adoptive immunotherapy.

\begin{tabular}{|c|c|c|c|c|c|c|c|}
\hline $\begin{array}{l}\text { Clinical trial } \\
\text { identifier }\end{array}$ & $\begin{array}{l}\text { Trial } \\
\text { phase }\end{array}$ & Disease & $\begin{array}{l}\text { Type of } \\
\text { transplant }\end{array}$ & Conditioning regimen & $\begin{array}{l}\text { CB NK } \\
\text { infusion day }\end{array}$ & Dose & Expansion \\
\hline NCT01619761 & 1 & $\begin{array}{l}\text { AML, ALL, CML, MDS, } \\
\text { NHL, SLL, CLL, NHL, HL, } \\
\text { MM }\end{array}$ & DCBT & $\begin{array}{l}\text { Fludarabine, melphalan, } \\
\text { lenalidomide } \pm \text { rituximab }\end{array}$ & Day 2 & $5 \times 10^{6} / \mathrm{kg}$ & $\begin{array}{l}\text { Ex vivo from } \\
20 \% \text { CB unit } \\
\text { fraction }\end{array}$ \\
\hline NCT01729091 & $|/| \mid$ & Multiple myeloma & Autologous & $\begin{array}{l}\text { Melphalan, lenalidomide } \\
\text { (day 8-2) }\end{array}$ & Day 5 & $5 \times 10^{6}-1 \times 10^{8} / \mathrm{kg}$ & $\begin{array}{l}\text { Ex vivo } \\
\text { expanded from } \\
\text { thawed CB unit }\end{array}$ \\
\hline NCT02280525 & 1 & $\begin{array}{l}\text { CLL refractory to at } \\
\text { least } 2 \text { lines of standard } \\
\text { chemoimmunotherapy, } \\
\text { relapsed or refractory ALL, } \\
\text { AML, CML, NHL, HL }\end{array}$ & $\begin{array}{l}\text { Non-transplant } \\
\text { setting }\end{array}$ & $\begin{array}{l}\text { Fludarabine, } \\
\text { cyclophosphamide, } \\
\text { rituximab, and lenalidomide } \\
\text { (day } 5 \text { to +14) }\end{array}$ & Day 0 & $\begin{array}{l}\text { Escalating doses } \\
\left(10^{6}-10^{8} / \mathrm{kg}\right)\end{array}$ & $\begin{array}{l}\text { Ex vivo } \\
\text { expanded from } \\
\text { thawed CB unit }\end{array}$ \\
\hline NCT01823198 & $|/| \mid$ & Myeloid malignancies & Allogeneic & Busulfan, fludarabine & Day $8^{a}$ & $\begin{array}{l}10^{6}, 10^{7}, 3 \times 10^{7} \text {, } \\
\text { or } 10^{8} / \mathrm{kg} \text { based on } \\
\text { number of NK cells }\end{array}$ & $\begin{array}{l}\text { Ex vivo + in vivo } \\
\text { expansion with } \\
\text { IL-2 (day 8-4) }\end{array}$ \\
\hline
\end{tabular}

aNK cell source could be from matched related donor, haploidentical donor, or $C B$.

ALL, acute lymphoblastic leukemia; AML, acute myeloid leukemia; CB, cord blood; CLL, chronic lymphoblastic leukemia; CML, chronic myeloid leukemia; DCBT; double unit cord blood transplantation; HL, Hodgkin lymphoma; MDS, myelodysplastic syndromes; MM, multiple myeloma; NHL, non-Hodgkin lymphoma; NK, natural killer; SLL, small lymphocytic lymphoma.

The impact of KIR haplotype on CBT outcomes has not been evaluated to date.

\section{Role of NK Cell Licensing Post Transplantation}

Evaluation of the impact of NK cell licensing, a process by which NK cells gain functional competence (118), should be considered in future studies of CBT. The new MHC environment of the recipient can alter NK cell responsiveness (119). In an elegant study performed by Joncker et al. (119), adoptive transfer of mature functional NK cells from MHC-I wild-type mice into MHC-Ideficient mice resulted in loss of NK cell responsiveness. By contrast, transfer of hyporesponsive NK cells from MHC-I-deficient mice into MHC-I wild-type mice resulted in gain of functional competency. A recent study of unrelated donor PB/BM HSCT recipients provided clinical evidence for the significance of this dynamic process of licensing in humans. The authors found that patients who lacked cognate ligands involved in NK cell licensing for the inhibitory KIRs in the donor had significantly worse DFS, OS, and time to progression, compared with patients who had the ligands. This supports the principle that activated licensed NK cells are significantly more cytotoxic than the unlicensed cells and are more likely to mediate a strong graft vs. leukemia response (118).

\section{CORD BLOOD NK CELLS IN CELLULAR THERAPIES}

In addition to the role of $\mathrm{NK}$ cells in CBT, the use of ex vivo purified and activated CB NK cells is also being explored for adoptive immunotherapy. Although numerous studies have been conducted using autologous or allogeneic (PB or BM) NK cells infusions [reviewed in Ref. (120-122)], no clinical study to date has reported on the use $\mathrm{CB}$ NK cells. A handful of clinical trials are currently underway to evaluate the feasibility, safety, and efficacy of CB NK cell adoptive immunotherapy in transplant and non-transplant settings (Table 2).

\section{CONCLUSION}

Natural killer cells have a remarkable potential to kill cancer as well as virally infected cells. They are the first cells to reconstitute after HSCT (8-14), they facilitate engraftment (78), they do not cause GVHD, and they may even prevent this complication by eliminating host antigen-presenting cells and donor alloreactive $\mathrm{T}$ cells $(83,123)$. CB provides several distinctive benefits, and it is increasingly used as a source of CBT and cellular therapies. Resting CB NK cells are immature and are poorly cytotoxic compared with PB NK cells; however, these limitations can be overcome by ex vivo expansion using cytokines and feeder cells $(48,49,52,56,124)$. A number of clinical studies are evaluating the feasibility, safety, and antitumor efficacy of adoptive immunotherapy with CB NK cells. The biological mechanism and tempo of NK cell alloreactivity after CBT, especially with double unit CBT has not been fully elucidated. Before the immunological reactivity of NK cells and KIRs could be targeted and exploited to improve the response to CBT, we will need to have a better understanding of the biological mechanisms involved in NK-mediated anti-leukemia response.

\section{AUTHOR CONTRIBUTIONS}

RM, ES, and KR wrote and edited the manuscript. 


\section{REFERENCES}

1. Pasquini MC, Zhu X. Current Uses and Outcomes of Hematopoietic Stem Cell Transplantation: 2014 CIBMTR Summary Slides (2014). Available from: http://www.cibmtr.org

2. Kim YJ, Broxmeyer HE. Immune regulatory cells in umbilical cord blood and their potential roles in transplantation tolerance. Crit Rev Oncol Hematol (2011) 79(2):112-26. doi:10.1016/j.critrevonc.2010.07.009

3. Danby R, Rocha V. Improving engraftment and immune reconstitution in umbilical cord blood transplantation. Front Immunol (2014) 5:68. doi:10.3389/fimmu.2014.00068

4. Brunstein CG, Barker JN, Weisdorf DJ, DeFor TE, Miller JS, Blazar BR, et al. Umbilical cord blood transplantation after nonmyeloablative conditioning: impact on transplantation outcomes in 110 adults with hematologic disease. Blood (2007) 110(8):3064-70. doi:10.1182/blood-2007-04-067215

5. Rodrigues CA, Sanz G, Brunstein CG, Sanz J, Wagner JE, Renaud M, et al. Analysis of risk factors for outcomes after unrelated cord blood transplantation in adults with lymphoid malignancies: a study by the EurocordNetcord and lymphoma working party of the European group for blood and marrow transplantation. J Clin Oncol (2009) 27(2):256-63. doi:10.1200/ JCO.2007.15.8865

6. Verneris MR, Brunstein CG, Barker J, MacMillan ML, DeFor T, McKenna $\mathrm{DH}$, et al. Relapse risk after umbilical cord blood transplantation: enhanced graft-versus-leukemia effect in recipients of 2 units. Blood (2009) 114(19):4293-9. doi:10.1182/blood-2009-05-220525

7. Gutman JA, Leisenring W, Appelbaum FR, Woolfrey AE, Delaney C. Low relapse without excessive transplant-related mortality following myeloablative cord blood transplantation for acute leukemia in complete remission: a matched cohort analysis. Biol Blood Marrow Transplant (2009) 15(9):1122-9. doi:10.1016/j.bbmt.2009.05.014

8. Small TN, Papadopoulos EB, Boulad F, Black P, Castro-Malaspina H, Childs $\mathrm{BH}$, et al. Comparison of immune reconstitution after unrelated and related T-cell-depleted bone marrow transplantation: effect of patient age and donor leukocyte infusions. Blood (1999) 93(2):467-80.

9. Thomson BG, Robertson KA, Gowan D, Heilman D, Broxmeyer HE, Emanuel D, et al. Analysis of engraftment, graft-versus-host disease, and immune recovery following unrelated donor cord blood transplantation. Blood (2000) 96(8):2703-11.

10. Ruggeri A, Peffault de Latour R, Carmagnat M, Clave E, Douay C, Larghero J, et al. Outcomes, infections, and immune reconstitution after double cord blood transplantation in patients with high-risk hematological diseases. Transpl Infect Dis (2011) 13(5):456-65. doi:10.1111/j.1399-3062.2011.00632.x

11. Jacobson CA, Turki AT, McDonough SM, Stevenson KE, Kim HT, Kao G, et al. Immune reconstitution after double umbilical cord blood stem cell transplantation: comparison with unrelated peripheral blood stem cell transplantation. Biol Blood Marrow Transplant (2012) 18(4):565-74. doi:10.1016/j. bbmt.2011.08.018

12. Somers JA, Brand A, van Hensbergen Y, Mulder A, Oudshoorn M, Sintnicolaas K, et al. Double umbilical cord blood transplantation: a study of early engraftment kinetics in leukocyte subsets using HLA-specific monoclonal antibodies. Biol Blood Marrow Transplant (2013) 19(2):266-73. doi:10.1016/j.bbmt.2012.09.022

13. Saliba RM, Rezvani K, Leen A, Jorgensen J, Shah N, Hosing C, et al. General and virus-specific immune cell reconstitution after double cord blood transplantation. Biol Blood Marrow Transplant (2015) 21(7):1284-90. doi:10.1016/j.bbmt.2015.02.017

14. Brahmi Z, Hommel-Berrey G, Smith F, Thomson B. NK cells recover early and mediate cytotoxicity via perforin/granzyme and Fas/FasL pathways in umbilical cord blood recipients. Hum Immunol (2001) 62(8):782-90. doi:10.1016/S0198-8859(01)00275-0

15. Robertson MJ, Ritz J. Biology and clinical relevance of human natural killer cells. Blood (1990) 76(12):2421-38.

16. Cooper MA, Fehniger TA, Caligiuri MA. The biology of human natural killer-cell subsets. Trends Immunol (2001) 22(11):633-40. doi:10.1016/ S1471-4906(01)02060-9

17. Fehniger TA, Cooper MA, Nuovo GJ, Cella M, Facchetti F, Colonna M, et al. CD56bright natural killer cells are present in human lymph nodes and are activated by $\mathrm{T}$ cell-derived IL-2: a potential new link between adaptive and innate immunity. Blood (2003) 101(8):3052-7. doi:10.1182/ blood-2002-09-2876

18. Lanier LL, Le AM, Civin CI, Loken MR, Phillips JH. The relationship of CD16 (Leu-11) and Leu-19 (NKH-1) antigen expression on human peripheral blood NK cells and cytotoxic T lymphocytes. J Immunol (1986) 136(12):4480-6.

19. Jacobs R, Hintzen G, Kemper A, Beul K, Kempf S, Behrens G, et al. CD56bright cells differ in their KIR repertoire and cytotoxic features from CD56dim NK cells. Eur JImmunol (2001) 31(10):3121-7. doi:10.1002/1521-4141(2001010)31:10<3121::AID-IMMU3121>3.0.CO;2-4

20. Nagler A, Lanier LL, Cwirla S, Phillips JH. Comparative studies of human FcRIII-positive and negative natural killer cells. J Immunol (1989) 143(10):3183-91.

21. Matos ME, Schnier GS, Beecher MS, Ashman LK, William DE, Caligiuri MA. Expression of a functional c-kit receptor on a subset of natural killer cells. J Exp Med (1993) 178(3):1079-84. doi:10.1084/jem.178.3.1079

22. Carson WE, Fehniger TA, Caligiuri MA. CD56bright natural killer cell subsets: characterization of distinct functional responses to interleukin-2 and the c-kit ligand. Eur J Immunol (1997) 27(2):354-60. doi:10.1002/eji.1830270203

23. Cooper MA, Fehniger TA, Turner SC, Chen KS, Ghaheri BA, Ghayur T, et al. Human natural killer cells: a unique innate immunoregulatory role for the CD56(bright) subset. Blood (2001) 97(10):3146-51. doi:10.1182/blood. V97.10.3146

24. Vitale M, Della Chiesa M, Carlomagno S, Romagnani C, Thiel A, Moretta L, et al. The small subset of CD56brightCD16- natural killer cells is selectively responsible for both cell proliferation and interferon-gamma production upon interaction with dendritic cells. Eur J Immunol (2004) 34(6):1715-22. doi:10.1002/eji.200425100

25. Robertson MJ, Manley TJ, Donahue C, Levine H, Ritz J. Costimulatory signals are required for optimal proliferation of human natural killer cells. J Immunol (1993) 150(5):1705-14.

26. Baume DM, Robertson MJ, Levine H, Manley TJ, Schow PW, Ritz J. Differential responses to interleukin 2 define functionally distinct subsets of human natural killer cells. Eur J Immunol (1992) 22(1):1-6. doi:10.1002/ eji. 1830220102

27. Munoz J, Shah N, Rezvani K, Hosing C, Bollard CM, Oran B, et al. Concise review: umbilical cord blood transplantation: past, present, and future. Stem Cells Transl Med (2014) 3(12):1435-43. doi:10.5966/sctm.2014-0151

28. Oran B, Shpall E. Umbilical cord blood transplantation: a maturing technology. Hematol Am Soc Hematol Educ Program (2012) 2012:215-22. doi:10.1182/asheducation-2012.1.215

29. Eapen M, Rubinstein P, Zhang MJ, Stevens C, Kurtzberg J, Scaradavou A, et al. Outcomes of transplantation of unrelated donor umbilical cord blood and bone marrow in children with acute leukaemia: a comparison study. Lancet (2007) 369(9577):1947-54. doi:10.1016/S0140-6736(07)60915-5

30. Laughlin MJ, Eapen M, Rubinstein P, Wagner JE, Zhang MJ, Champlin RE, et al. Outcomes after transplantation of cord blood or bone marrow from unrelated donors in adults with leukemia. N Engl J Med (2004) 351(22):226575. doi:10.1056/NEJMoa041276

31. Rocha V, Labopin M, Sanz G, Arcese W, Schwerdtfeger R, Bosi A, et al. Transplants of umbilical-cord blood or bone marrow from unrelated donors in adults with acute leukemia. N Engl J Med (2004) 351(22):2276-85. doi:10.1056/NEJMoa041469

32. Atsuta Y, Suzuki R, Nagamura-Inoue T, Taniguchi S, Takahashi S, Kai S, et al. Disease-specific analyses of unrelated cord blood transplantation compared with unrelated bone marrow transplantation in adult patients with acute leukemia. Blood (2009) 113(8):1631-8. doi:10.1182/blood-2008-03-147041

33. Takahashi S, Ooi J, Tomonari A, Konuma T, Tsukada N, Oiwa-Monna M, et al. Comparative single-institute analysis of cord blood transplantation from unrelated donors with bone marrow or peripheral blood stem-cell transplants from related donors in adult patients with hematologic malignancies after myeloablative conditioning regimen. Blood (2007) 109(3):1322-30.

34. Marchant A, Goldman M. T cell-mediated immune responses in human newborns: ready to learn? Clin Exp Immunol (2005) 141(1):10-8. doi:10.1111/j.1365-2249.2005.02799.x

35. Park KD, Marti L, Kurtzberg J, Szabolcs P. In vitro priming and expansion of cytomegalovirus-specific Th1 and Tc1 T cells from naive cord blood lymphocytes. Blood (2006) 108(5):1770-3. doi:10.1182/blood-2005-10-006536

36. Nomura A, Takada $\mathrm{H}$, Jin $\mathrm{CH}$, Tanaka $\mathrm{T}$, Ohga $\mathrm{S}$, Hara T. Functional analyses of cord blood natural killer cells and $\mathrm{T}$ cells: a distinctive 
interleukin-18 response. Exp Hematol (2001) 29(10):1169-76. doi:10.1016/ S0301-472X(01)00689-0

37. Brunstein CG, Gutman JA, Weisdorf DJ, Woolfrey AE, Defor TE, Gooley $\mathrm{TA}$, et al. Allogeneic hematopoietic cell transplantation for hematologic malignancy: relative risks and benefits of double umbilical cord blood. Blood (2010) 116(22):4693-9. doi:10.1182/blood-2010-05-285304

38. Konuma T, Kato S, Ooi J, Oiwa-Monna M, Kawamata T, Tojo A, et al. Comparable long-term outcome of unrelated cord blood transplantation with related bone marrow or peripheral blood stem cell transplantation in patients aged 45 years or older with hematologic malignancies after myeloablative conditioning. Biol Blood Marrow Transplant (2014) 20(8):1150-5. doi:10.1016/j.bbmt.2014.04.005

39. Eapen M, Rocha V, Sanz G, Scaradavou A, Zhang MJ, Arcese W, et al. Effect of graft source on unrelated donor haemopoietic stem-cell transplantation in adults with acute leukaemia: a retrospective analysis. Lancet Oncol (2010) 11(7):653-60. doi:10.1016/S1470-2045(10)70127-3

40. Chen YB, Aldridge J, Kim HT, Ballen KK, Cutler C, Kao G, et al. Reduced-intensity conditioning stem cell transplantation: comparison of double umbilical cord blood and unrelated donor grafts. Biol Blood Marrow Transplant (2012) 18(5):805-12. doi:10.1016/j.bbmt.2011.10.016

41. Cooley S, McCullar V, Wangen R, Bergemann TL, Spellman S, Weisdorf $\mathrm{DJ}$, et al. KIR reconstitution is altered by $\mathrm{T}$ cells in the graft and correlates with clinical outcomes after unrelated donor transplantation. Blood (2005) 106(13):4370-6. doi:10.1182/blood-2005-04-1644

42. Nguyen S, Kuentz M, Vernant JP, Dhedin N, Bories D, Debré P, et al. Involvement of mature donor $\mathrm{T}$ cells in the NK cell reconstitution after haploidentical hematopoietic stem-cell transplantation. Leukemia (2008) 22(2):344-52. doi:10.1038/sj.leu.2405041

43. Rutella S, Bonanno G, Marone M, De Ritis D, Mariotti A, Voso MT, et al. Identification of a novel subpopulation of human cord blood CD34-CD133CD7-CD45+lineage- cells capable of lymphoid/NK cell differentiation after in vitro exposure to IL-15. J Immunol (2003) 171(6):2977-88. doi:10.4049/ jimmunol.171.6.2977

44. McCullar V, Oostendorp R, Panoskaltsis-Mortari A, Yun G, Lutz CT, Wagner JE, et al. Mouse fetal and embryonic liver cells differentiate human umbilical cord blood progenitors into CD56-negative natural killer cell precursors in the absence of interleukin-15. Exp Hematol (2008) 36(5):598-608. doi:10.1016/j. exphem.2008.01.001

45. Miller JS, McCullar V. Human natural killer cells with polyclonal lectin and immunoglobulin-like receptors develop from single hematopoietic stem cells with preferential expression of NKG2A and KIR2DL2/L3/S2. Blood (2001) 98(3):705-13. doi:10.1182/blood.V98.3.705

46. Theilgaard-Mönch K, Raaschou-Jensen K, Palm H, Schjødt K, Heilmann C, Vindeløv L, et al. Flow cytometric assessment of lymphocyte subsets, lymphoid progenitors, and hematopoietic stem cells in allogeneic stem cell grafts. Bone Marrow Transplant (2001) 28(11):1073-82. doi:10.1038/ sj.bmt. 1703270

47. Perez SA, Sotiropoulou PA, Gkika DG, Mahaira LG, Niarchos DK, Gritzapis $\mathrm{AD}$, et al. A novel myeloid-like NK cell progenitor in human umbilical cord blood. Blood (2003) 101(9):3444-50. doi:10.1182/blood-2002-05-1501

48. Gaddy J, Broxmeyer HE. Cord blood CD16+56- cells with low lytic activity are possible precursors of mature natural killer cells. Cell Immunol (1997) 180(2):132-42. doi:10.1006/cimm.1997.1175

49. Bradstock KF, Luxford C, Grimsley PG. Functional and phenotypic assessment of neonatal human leucocytes expressing natural killer cell-associated antigens. Immunol Cell Biol (1993) 71(Pt 6):535-42. doi:10.1038/ icb.1993.59

50. Luevano M, Daryouzeh M, Alnabhan R, Querol S, Khakoo S, Madrigal A, et al. The unique profile of cord blood natural killer cells balances incomplete maturation and effective killing function upon activation. Hum Immunol (2012) 73(3):248-57. doi:10.1016/j.humimm.2011.12.015

51. Tanaka H, Kai S, Yamaguchi M, Misawa M, Fujimori Y, Yamamoto M, et al. Analysis of natural killer (NK) cell activity and adhesion molecules on NK cells from umbilical cord blood. Eur J Haematol (2003) 71(1):29-38. doi:10.1034/j.1600-0609.2003.00081.x

52. Dalle JH, Menezes J, Wagner E, Blagdon M, Champagne J, Champagne MA, et al. Characterization of cord blood natural killer cells: implications for transplantation and neonatal infections. Pediatr Res (2005) 57(5 Pt 1):649-55. doi:10.1203/01.PDR.0000156501.55431.20
53. Wang Y, Xu H, Zheng X, Wei H, Sun R, Tian Z. High expression of NKG2A/ CD94 and low expression of granzyme $\mathrm{B}$ are associated with reduced cord blood NK cell activity. Cell Mol Immunol (2007) 4(5):377-82.

54. Björkström NK, Riese P, Heuts F, Andersson S, Fauriat C, Ivarsson MA, et al. Expression patterns of NKG2A, KIR, and CD57 define a process of CD56dim NK-cell differentiation uncoupled from NK-cell education. Blood (2010) 116(19):3853-64. doi:10.1182/blood-2010-04-281675

55. Abo T, Miller CA, Balch CM. Characterization of human granular lymphocyte subpopulations expressing HNK-1 (Leu-7) and Leu-11 antigens in the blood and lymphoid tissues from fetuses, neonates and adults. Eur I Immunol (1984) 14(7):616-23. doi:10.1002/eji.1830140707

56. Shah N, Martin-Antonio B, Yang H, Ku S, Lee DA, Cooper LJ, et al. Antigen presenting cell-mediated expansion of human umbilical cord blood yields log-scale expansion of natural killer cells with anti-myeloma activity. PLoS One (2013) 8(10):e76781. doi:10.1371/journal.pone.0076781

57. Spanholtz J, Preijers F, Tordoir M, Trilsbeek C, Paardekooper J, de Witte T, et al. Clinical-grade generation of active NK cells from cord blood hematopoietic progenitor cells for immunotherapy using a closed-system culture process. PLoS One (2011) 6(6):e20740. doi:10.1371/journal.pone.0020740

58. Spanholtz J, Tordoir M, Eissens D, Preijers F, van der Meer A, Joosten I, et al. High log-scale expansion of functional human natural killer cells from umbilical cord blood CD34-positive cells for adoptive cancer immunotherapy. PLoS One (2010) 5(2):e9221. doi:10.1371/journal.pone.0009221

59. Kao IT, Yao CL, Kong ZL, Wu ML, Chuang TL, Hwang SM. Generation of natural killer cells from serum-free, expanded human umbilical cord blood CD34+ cells. Stem Cells Dev (2007) 16(6):1043-51. doi:10.1089/ scd. 2007.0033

60. Giron-Michel J, Giuliani M, Fogli M, Brouty-Boyé D, Ferrini S, Baychelier F, et al. Membrane-bound and soluble IL-15/IL-15Ralpha complexes display differential signaling and functions on human hematopoietic progenitors. Blood (2005) 106(7):2302-10. doi:10.1182/blood-2005-01-0064

61. Xing D, Ramsay AG, Gribben JG, Decker WK, Burks JK, Munsell M, et al. Cord blood natural killer cells exhibit impaired lytic immunological synapse formation that is reversed with IL-2 exvivo expansion. J Immunother (2010) 33(7):684-96. doi:10.1097/CJI.0b013e3181e475e9

62. Koehl U, Esser R, Zimmermann S, Tonn T, Kotchetkov R, Bartling T, et al. Ex vivo expansion of highly purified NK cells for immunotherapy after haploidentical stem cell transplantation in children. Klin Padiatr (2005) 217(6):345-50. doi:10.1055/s-2005-872520

63. Tomchuck SL, Leung WH, Dallas MH. Enhanced cytotoxic function of natural killer and CD3+CD56+ cells in cord blood after culture. Biol Blood Marrow Transplant (2015) 21(1):39-49. doi:10.1016/j.bbmt.2014.10.014

64. Li Y, Schmidt-Wolf IG, Wu YF, Huang SL, Wei J, Fang J, et al. Optimized protocols for generation of cord blood-derived cytokine-induced killer/ natural killer cells. Anticancer Res (2010) 30(9):3493-9.

65. Boissel L, Tuncer HH, Betancur M, Wolfberg A, Klingemann H. Umbilical cord mesenchymal stem cells increase expansion of cord blood natural killer cells. Biol Blood Marrow Transplant (2008) 14(9):1031-8. doi:10.1016/j. bbmt.2008.06.016

66. Farag SS, Fehniger TA, Ruggeri L, Velardi A, Caligiuri MA. Natural killer cell receptors: new biology and insights into the graft-versus-leukemia effect. Blood (2002) 100(6):1935-47. doi:10.1182/blood-2002-02-0350

67. Moretta A, Bottino C, Vitale M, Pende D, Cantoni C, Mingari MC, et al. Activating receptors and coreceptors involved in human natural killer cell-mediated cytolysis. Annu Rev Immunol (2001) 19:197-223. doi:10.1146/ annurev.immunol.19.1.197

68. Parham P. MHC class I molecules and KIRs in human history, health and survival. Nat Rev Immunol (2005) 5(3):201-14. doi:10.1038/nri1570

69. Moretta L, Moretta A. Killer immunoglobulin-like receptors. Curr Opin Immunol (2004) 16(5):626-33. doi:10.1016/j.coi.2004.07.010

70. Yokoyama WM. Natural killer cell receptors. Curr Opin Immunol (1998) 10(3):298-305. doi:10.1016/S0952-7915(98)80168-4

71. Lanier LL. Face off - the interplay between activating and inhibitory immune receptors. Curr Opin Immunol (2001) 13(3):326-31. doi:10.1016/ S0952-7915(00)00222-3

72. Costello RT, Gastaut JA, Olive D. Tumor escape from immune surveillance. Arch Immunol Ther Exp (Warsz) (1999) 47(2):83-8.

73. Algarra I, Garcia-Lora A, Cabrera T, Ruiz-Cabello F, Garrido F. The selection of tumor variants with altered expression of classical and nonclassical MHC 
class I molecules: implications for tumor immune escape. Cancer Immunol Immunother (2004) 53(10):904-10.

74. Harel-Bellan A, Quillet A, Marchiol C, DeMars R, Tursz T, Fradelizi D. Natural killer susceptibility of human cells may be regulated by genes in the HLA region on chromosome 6. Proc Natl Acad Sci U S A (1986) 83(15):5688-92. doi:10.1073/pnas.83.15.5688

75. Ljunggren HG, Karre K. In search of the 'missing self': MHC molecules and NK cell recognition. Immunol Today (1990) 11(7):237-44. doi:10.1016/0167-5699(90)90097-S

76. Horton R, Wilming L, Rand V, Lovering RC, Bruford EA, Khodiyar VK, et al. Gene map of the extended human MHC. Nat Rev Genet (2004) 5(12):889-99. doi:10.1038/nrg1489

77. Bashirova AA, Martin MP, McVicar DW, Carrington M. The killer immunoglobulin-like receptor gene cluster: tuning the genome for defense. Annu Rev Genomics Hum Genet (2006) 7:277-300. doi:10.1146/annurev. genom.7.080505.115726

78. Ruggeri L, Capanni M, Casucci M, Volpi I, Tosti A, Perruccio K, et al. Role of natural killer cell alloreactivity in HLA-mismatched hematopoietic stem cell transplantation. Blood (1999) 94(1):333-9.

79. Hsu KC, Keever-Taylor CA, Wilton A, Pinto C, Heller G, Arkun K, et al. Improved outcome in HLA-identical sibling hematopoietic stem-cell transplantation for acute myelogenous leukemia predicted by KIR and HLA genotypes. Blood (2005) 105(12):4878-84. doi:10.1182/blood-2004-12-4825

80. Ruggeri L, Mancusi A, Capanni M, Urbani E, Carotti A, Aloisi T, et al. Donor natural killer cell allorecognition of missing self in haploidentical hematopoietic transplantation for acute myeloid leukemia: challenging its predictive value. Blood (2007) 110(1):433-40. doi:10.1182/blood-2006-07-038687

81. Leung W, Iyengar R, Turner V, Lang P, Bader P, Conn P, et al. Determinants of antileukemia effects of allogeneic NK cells. J Immunol (2004) 172(1):644-50. doi:10.4049/jimmunol.172.1.644

82. Leung W, Iyengar R, Triplett B, Turner V, Behm FG, Holladay MS, et al. Comparison of killer Ig-like receptor genotyping and phenotyping for selection of allogeneic blood stem cell donors. J Immunol (2005) 174(10):6540-5. doi:10.4049/jimmunol.174.10.6540

83. Ruggeri L, Capanni M, Urbani E, Perruccio K, Shlomchik WD, Tosti A, et al. Effectiveness of donor natural killer cell alloreactivity in mismatched hematopoietic transplants. Science (2002) 295(5562):2097-100. doi:10.1126/ science. 1068440

84. Davies SM, Ruggieri L, DeFor T, Wagner JE, Weisdorf DJ, Miller JS, et al. Evaluation of KIR ligand incompatibility in mismatched unrelated donor hematopoietic transplants. Killer immunoglobulin-like receptor. Blood (2002) 100(10):3825-7. doi:10.1182/blood-2002-04-1197

85. Lowe EJ, Turner V, Handgretinger R, Horwitz EM, Benaim E, Hale GA, et al. T-cell alloreactivity dominates natural killer cell alloreactivity in minimally T-cell-depleted HLA-non-identical paediatric bone marrow transplantation. Br J Haematol (2003) 123(2):323-6. doi:10.1046/j.1365-2141.2003.04604.x

86. Bornhauser M, Schwerdtfeger R, Martin H, Frank KH, Theuser C, Ehninger G. Role of KIR ligand incompatibility in hematopoietic stem cell transplantation using unrelated donors. Blood (2004) 103(7):2860-1; author reply 2862. doi:10.1182/blood-2003-11-3893

87. Sun JY, Dagis A, Gaidulis L, Miller MM, Rodriguez R, Parker P, et al. Detrimental effect of natural killer cell alloreactivity in T-replete hematopoietic cell transplantation (HCT) for leukemia patients. Biol Blood Marrow Transplant (2007) 13(2):197-205. doi:10.1016/j.bbmt.2006.09.009

88. Chen C, Busson M, Rocha V, Appert ML, Lepage V, Dulphy N, et al. Activating KIR genes are associated with CMV reactivation and survival after non-T-cell depleted HLA-identical sibling bone marrow transplantation for malignant disorders. Bone Marrow Transplant (2006) 38(6):437-44. doi:10.1038/ sj.bmt. 1705468

89. Giebel S, Locatelli F, Lamparelli T, Velardi A, Davies S, Frumento G, et al. Survival advantage with KIR ligand incompatibility in hematopoietic stem cell transplantation from unrelated donors. Blood (2003) 102(3):814-9. doi:10.1182/blood-2003-01-0091

90. Beelen DW, Ottinger HD, Ferencik S, Elmaagacli AH, Peceny R, Trenschel $\mathrm{R}$, et al. Genotypic inhibitory killer immunoglobulin-like receptor ligand incompatibility enhances the long-term antileukemic effect of unmodified allogeneic hematopoietic stem cell transplantation in patients with myeloid leukemias. Blood (2005) 105(6):2594-600. doi:10.1182/blood-2004-04-1441
91. Farag SS, Bacigalupo A, Eapen M, Hurley C, Dupont B, Caligiuri MA, et al. The effect of KIR ligand incompatibility on the outcome of unrelated donor transplantation: a report from the center for international blood and marrow transplant research, the European blood and marrow transplant registry, and the Dutch registry. Biol Blood Marrow Transplant (2006) 12(8):876-84. doi:10.1016/j.bbmt.2006.05.007

92. Hsu KC, Gooley T, Malkki M, Pinto-Agnello C, Dupont B, Bignon JD, et al. KIR ligands and prediction of relapse after unrelated donor hematopoietic cell transplantation for hematologic malignancy. Biol Blood Marrow Transplant (2006) 12(8):828-36. doi:10.1016/j.bbmt.2006.04.008

93. Miller JS, Cooley S, Parham P, Farag SS, Verneris MR, McQueen KL, et al. Missing KIR ligands are associated with less relapse and increased graft-versus-host disease (GVHD) following unrelated donor allogeneic HCT. Blood (2007) 109(11):5058-61. doi:10.1182/blood-2007-01-065383

94. Brunstein CG, Wagner JE, Weisdorf DJ, Cooley S, Noreen H, Barker JN, et al. Negative effect of KIR alloreactivity in recipients of umbilical cord blood transplant depends on transplantation conditioning intensity. Blood (2009) 113(22):5628-34. doi:10.1182/blood-2008-12-197467

95. Garfall A, Kim HT, Sun L, Ho VT, Armand P, Koreth J, et al. KIR ligand incompatibility is not associated with relapse reduction after double umbilical cord blood transplantation. Bone Marrow Transplant (2013) 48(7):1000-2. doi:10.1038/bmt.2012.272

96. Tanaka J, Morishima Y, Takahashi Y, Yabe T, Oba K, Takahashi S, et al. Effects of KIR ligand incompatibility on clinical outcomes of umbilical cord blood transplantation without ATG for acute leukemia in complete remission. Blood Cancer J (2013) 3:e164. doi:10.1038/bcj.2013.62

97. Willemze R, Rodrigues CA, Labopin M, Sanz G, Michel G, Socié G, et al. KIRligand incompatibility in the graft-versus-host direction improves outcomes after umbilical cord blood transplantation for acute leukemia. Leukemia (2009) 23(3):492-500. doi:10.1038/leu.2008.365

98. Shaw J, Kollnberger S. New perspectives on the ligands and function of the killer cell immunoglobulin-like receptor KIR3DL2 in health and disease. Front Immunol (2012) 3:339. doi:10.3389/fimmu.2012.00339

99. Hansasuta P, Dong T, Thananchai H, Weekes M, Willberg C, Aldemir H, et al. Recognition of HLA-A3 and HLA-A11 by KIR3DL2 is peptide-specific. Eur J Immunol (2004) 34(6):1673-9. doi:10.1002/eji.200425089

100. Augusto DG, O'Connor GM, Lobo-Alves SC, Bass S, Martin MP, Carrington $M$, et al. Pemphigus is associated with KIR3DL2 expression levels and provides evidence that KIR3DL2 may bind HLA-A3 and A11 in vivo. Eur J Immunol (2015) 45(7):2052-60. doi:10.1002/eji.201445324

101. Willemze R, Ruggeri A, Purtill D, Rodrigues CA, Gluckman E, Rocha V, et al. Is there an impact of killer cell immunoglobulin-like receptors and KIR-ligand incompatibilities on outcomes after unrelated cord blood stem cell transplantation? Best Pract Res Clin Haematol (2010) 23(2):283-90. doi:10.1016/j.beha.2010.05.005

102. Wrzesinski C, Paulos CM, Kaiser A, Muranski P, Palmer DC, Gattinoni L, et al. Increased intensity lymphodepletion enhances tumor treatment efficacy of adoptively transferred tumor-specific T cells. J Immunother (2010) 33(1):1-7. doi:10.1097/CJI.0b013e3181b88ffc

103. Miller JS, Soignier Y, Panoskaltsis-Mortari A, McNearney SA, Yun GH, Fautsch SK, et al. Successful adoptive transfer and in vivo expansion of human haploidentical NK cells in patients with cancer. Blood (2005) 105(8):3051-7. doi:10.1182/blood-2004-07-2974

104. Dudley ME, Wunderlich JR, Robbins PF, Yang JC, Hwu P, Schwartzentruber DJ, et al. Cancer regression and autoimmunity in patients after clonal repopulation with antitumor lymphocytes. Science (2002) 298(5594):850-4. doi:10.1126/science.1076514

105. Bachanova V, Cooley S, Defor TE, Verneris MR, Zhang B, McKenna DH, et al. Clearance of acute myeloid leukemia by haploidentical natural killer cells is improved using IL-2 diphtheria toxin fusion protein. Blood (2014) 123(25):3855-63. doi:10.1182/blood-2013-10-532531

106. Lonnqvist B, Ringden O, Ljungman P, Wahren B, Gahrton G. Reduced risk of recurrent leukaemia in bone marrow transplant recipients after cytomegalovirus infection. Br J Haematol (1986) 63(4):671-9. doi:10.111 1/j.1365-2141.1986.tb07551.x

107. Foley B, Cooley S, Verneris MR, Pitt M, Curtsinger J, Luo X, et al. Cytomegalovirus reactivation after allogeneic transplantation promotes a lasting increase in educated NKG2C+ natural killer cells with potent function. Blood (2012) 119(11):2665-74. doi:10.1182/blood-2011-10-386995 
108. Della Chiesa M, Falco M, Podestà M, Locatelli F, Moretta L, Frassoni F, et al. Phenotypic and functional heterogeneity of human NK cells developing after umbilical cord blood transplantation: a role for human cytomegalovirus? Blood (2012) 119(2):399-410. doi:10.1182/blood-2011-08-372003

109. Della Chiesa M, Falco M, Bertaina A, Muccio L, Alicata C, Frassoni F, et al. Human cytomegalovirus infection promotes rapid maturation of NK cells expressing activating killer Ig-like receptor in patients transplanted with NKG2C-/- umbilical cord blood. J Immunol (2014) 192(4):1471-9. doi:10.4049/jimmunol.1302053

110. Guma M, Angulo A, Vilches C, Gomez-Lozano N, Malats N, Lopez-Botet M. Imprint of human cytomegalovirus infection on the NK cell receptor repertoire. Blood (2004) 104(12):3664-71. doi:10.1182/blood-2004-05-2058

111. Elmaagacli AH, Steckel NK, Koldehoff M, Hegerfeldt Y, Trenschel R, Ditschkowski $\mathrm{M}$, et al. Early human cytomegalovirus replication after transplantation is associated with a decreased relapse risk: evidence for a putative virus-versus-leukemia effect in acute myeloid leukemia patients. Blood (2011) 118(5):1402-12. doi:10.1182/blood-2010-08-304121

112. Green ML, Leisenring WM, Xie H, Walter RB, Mielcarek M, Sandmaier BM, et al. CMV reactivation after allogeneic HCT and relapse risk: evidence for early protection in acute myeloid leukemia. Blood (2013) 122(7):1316-24. doi:10.1182/blood-2013-02-487074

113. Cook MA, Milligan DW, Fegan CD, Darbyshire PJ, Mahendra P, Craddock $\mathrm{CF}$, et al. The impact of donor KIR and patient HLA-C genotypes on outcome following HLA-identical sibling hematopoietic stem cell transplantation for myeloid leukemia. Blood (2004) 103(4):1521-6. doi:10.1182/ blood-2003-02-0438

114. Schellekens J, Rozemuller EH, Petersen EJ, van den Tweel JG, Verdonck LF, Tilanus MG. Activating KIRs exert a crucial role on relapse and overall survival after HLA-identical sibling transplantation. Mol Immunol (2008) 45(8):2255-61. doi:10.1016/j.molimm.2007.11.014

115. Mancusi A, Ruggeri L, Urbani E, Pierini A, Massei MS, Carotti A, et al. Haploidentical hematopoietic transplantation from KIR ligand-mismatched donors with activating KIRs reduces nonrelapse mortality. Blood (2015) 125(20):3173-82. doi:10.1182/blood-2014-09-599993

116. Venstrom JM, Pittari G, Gooley TA, Chewning JH, Spellman S, Haagenson M, et al. HLA-C-dependent prevention of leukemia relapse by donor activating KIR2DS1. N Engl J Med (2012) 367(9):805-16. doi:10.1056/NEJMoa1200503
117. Cooley S, Trachtenberg E, Bergemann TL, Saeteurn K, Klein J, Le CT, et al. Donors with group B KIR haplotypes improve relapse-free survival after unrelated hematopoietic cell transplantation for acute myelogenous leukemia. Blood (2009) 113(3):726-32. doi:10.1182/blood-2008-07-171926

118. Kim S, Poursine-Laurent J, Truscott SM, Lybarger L, Song YJ, Yang L, et al. Licensing of natural killer cells by host major histocompatibility complex class I molecules. Nature (2005) 436(7051):709-13. doi:10.1038/nature03847

119. Joncker NT, Shifrin N, Delebecque F, Raulet DH. Mature natural killer cells reset their responsiveness when exposed to an altered MHC environment. $J$ Exp Med (2010) 207(10):2065-72. doi:10.1084/jem.20100570

120. Knorr DA, Bachanova V, Verneris MR, Miller JS. Clinical utility of natural killer cells in cancer therapy and transplantation. Semin Immunol (2014) 26(2):161-72. doi:10.1016/j.smim.2014.02.002

121. Bachanova V, Miller JS. NK cells in therapy of cancer. Crit Rev Oncog (2014) 19(1-2):133-41. doi:10.1615/CritRevOncog.2014011091

122. Cheng M, Chen Y, Xiao W, Sun R, Tian Z. NK cell-based immunotherapy for malignant diseases. Cell Mol Immunol (2013) 10(3):230-52. doi:10.1038/ cmi.2013.10

123. Olson JA, Leveson-Gower DB, Gill S, Baker J, Beilhack A, Negrin RS. NK cells mediate reduction of GVHD by inhibiting activated, alloreactive T cells while retaining GVT effects. Blood (2010) 115(21):4293-301. doi:10.1182/ blood-2009-05-222190

124. Choi SS, Chhabra VS, Nguyen QH, Ank BJ, Stiehm ER, Roberts RL. Interleukin-15 enhances cytotoxicity, receptor expression, and expansion of neonatal natural killer cells in long-term culture. Clin Diagn Lab Immunol (2004) 11(5):879-88.

Conflict of Interest Statement: The authors declare that the research was conducted in the absence of any commercial or financial relationships that could be construed as a potential conflict of interest.

Copyright (C) 2016 Mehta, Shpall and Rezvani. This is an open-access article distributed under the terms of the Creative Commons Attribution License (CC BY). The use, distribution or reproduction in other forums is permitted, provided the original author(s) or licensor are credited and that the original publication in this journal is cited, in accordance with accepted academic practice. No use, distribution or reproduction is permitted which does not comply with these terms. 